\title{
Optimasi Arsip Penyimpanan Dokumen Foto Menggunakan Algoritma Kompresi Deflate (Studi Kasus :Studio Muezzart)
}

\author{
Ahmad Bahrudin ${ }^{1)}$, Jupriyadi²), Permata ${ }^{3)}$ \\ ${ }^{1}$ Informatika, Universitas Teknokrat Indoenasia \\ ${ }^{1}$ Teknologi Informasi, Universitas Teknokrat Indoenasia

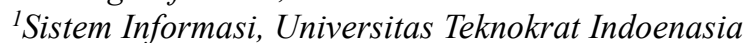 \\ Email:1ahmadbahrudin121@gmail.com,2jupriyadi@teknokrat.ac.id,2²permata@teknokrat.ac.id
}

\begin{abstract}
The existence of an archive for an organization is important, because it contains information that is important and has value for the organization. Muezzart Studio still does photo storage stored into a folder on the phone with such a lack of data security and the amount of photo capacity stored so that if more and more photos make memory is not enough or full and make people to delete old photos to store new photos. The results of this study of photo storage system are made almost every day storage. The application of the system that will be made supported by online-based applications that can later be applied through the internet network and storage can be done anytime and anywhere, and will use deflate algorithm was originally a compression concept created and implemented by Philip Katz. The system is built with prototype system development method and system testing using ISO 25010. Hasi testing that has been done by involving 4 Respondents that the conclusion of the quality of feasibility of the resulting software has a percentage of success with an average total of $88.93 \%$. So it can be concluded that the percentage value obtained indicates the overall quality of the software has a scale of "Excellent".
\end{abstract}

Keyword: Photo Storage, Deflate Protptype, ISO 25010

\begin{abstract}
Abstrak
Keberadaan sebuah arsip bagi suatu organisasi merupakan hal yang penting, karena di dalam arsip tersebut terkandung informasi-informasi yang penting dan memiliki nilai guna bagi organisasi. Studio Muezzart masih melakukan penyimpanan foto disimpan kedalam sebuah folder pada handphone dengana demikian kurangnya keamanan data serta besarnya kapasitas foto yang disimpan sehingga jika semakin banyak foto membuat memory tidak cukup atau penuh serta membuat masyarakat untuk menghapus foto lama untuk menyimpan foto baru. Hasil penelitian ini sistem penyimpanan foto dikarnakan penyimpanan hampir dilakukan setiap hari. Penerapan sistem yang akan dibuat di dukung oleh aplikasi berbasis online yang nantinya dapat diterapkan melalui jaringan internet dan penyimpanan dapat dilakukan kapan saja dan dimana saja, dan akan menggunakan algoritma deflate awal mulanya merupakan konsep kompresi yang dibuat dan diimplementasikan oleh Philip Katz. Sistem ini dibangun dengan metode pengembangan sistem prototype dan pengujian sistem menggunakan ISO 25010. Hasi pengujian yang telah dilakukan dengan melibatkan 4 Responden bahwa kesimpulan kualitas kelayakan perangkat lunak yang dihasilkan memiliki persentase keberhasilan dengan total rata-rata $88.93 \%$. Sehingga dapat disimpulkan bahwa nilai persentase yang diperoleh menunjukkan kualitas perangkat lunak secara keseluruhan mempunyai skala "Sangat Baik".
\end{abstract}

Kata Kunci: Penyimpanan Foto, deflate Protptype, ISO 25010

\section{Pendahuluan}

Seiring dengan perkembangan waktu dan teknologi, maka teknologi informasi juga mengalami perkembangan yang cukup signifikan. Pertukaran data dan informasi pun semakin bertambah. Data yang dahulu hanya bisa diolah dengan perangkat lunak yang terbatas kini bukan lagi menjadi masalah. Pemrosesan data bisa dilakukan dengan menggunakan perangkat lunak apa saja sesuai dengan kebutuhan. Seiring dengan berkembangnya teknologi dalam pengarsipan data itu, semakin besar pula ukuran dari data yang diarsipkan. Data tersebut tidak hanya berupa teks, bisa saja berupa gambar, suara, atau bahkan video yang membutuhkan ukuran data yang besar dan menyita ruang penyimpanan yang dimiliki[1].

Keberadaan sebuah arsip bagi suatu organisasi merupakan hal yang penting, karena di dalam arsip tersebut terkandung informasi-informasi yang penting dan memiliki nilai guna bagi organisasi. Selain itu karena manusia mempunyai daya ingat yang terbatas, maka arsip merupakan pusat ingatan yang tidak akan 
lupa dengan segala informasi yang terkandung di dalamnya. Arsip adalah rekaman kegiatan atau peristiwa dalam berbagai bentuk dan media sesuai dengan perkembangan teknologi informasi dan komunikasi yang dibuat dan diterima oleh lembaga negara, pemerintahan daerah, lembaga pendidikan, perusahaan, organisasi politik, organisasi kemasyarakatan, dan perseorangan dalam pelaksanaan kehidupan bermasyarakat, berbangsa, dan bernegara (PP 28 Tahun 2012).

Sebelum teknologi informasi berkembang seperti saat sekarang ini, banyak studio foto masih menggunakan penyimpanan menggunakan folder salah satunya studio Muezzart. Studio Muezzart bergerak dalam bidang jasa pemotretan didalam maupun di luar ruangan yang berlokasikan di Jl. Amir Hamzah No. 79, Gotong Royong, Kec. Tj. Karang Pusat, Kota Bandar Lampung. Studio Muezzart masih melakukan penyimpanan foto disimpan kedalam sebuah folder pada handphone dengan demikian penumpukan foto pada handphone, lama dalam proses pencarian foto, dan karyawan Studio Muezzart harus mengirim kebagian admin untuk proses pengarsipan.

Berdasarkan masalah penyimpanan foto maka perlu adanya sistem penyimpanan foto dikarnakan penyimpanan hampir dilakukan setiap hari. Penerapan sistem yang akan dibuat di dukung oleh aplikasi berbasis online yang nantinya dapat diterapkan melalui jaringan internet dan penyimpanan dapat dilakukan kapan saja dan dimana saja, dan akan menggunakan algoritma deflate awal mulanya merupakan konsep kompresi yang dibuat dan diimplementasikan oleh Philip Katz. Diharapkan sistem yang dibangun dapat menjadi aplikasi penyimpanan foto yang mudah digunakan, dan dalam proses pencarian data siaran bisa lebih cepat tanpa membuka satu persatu.

\section{Tinjauan Pustaka}

Kompresi Deflate awal mulanya merupakan konsep kompresi yang dibuat dan diimplementasikan oleh Philip Katz, salah satu implementasinya telah diterapkan di dalam kompresi file Zip. Program yang dibuat oleh Philip Katz dan mengimplementasi algoritma kompresi Deflate adalah software PKZIP. Metode kompresi Deflate merupakan kombinasi dari variant LZ77 dan metode Huffman Algoritma kompresi Deflate ini bersifat loseless sama seperti algoritma kompresi LZ77 dan algoritma kompresi Static Huffman[2]. Metode encoding pada Deflate telah dimuat dalam dokumen Request For Comments 1951. Ada 4 mode kompresi yang digunakan di dalam Deflate, namun mode keempat tidak digunakan. Adapun mode kompresi pada compressor Deflate yaitu:

1. Tidak dikompresi sama sekali. Kompresi dengan metode ini merupakan kompresi yang inputan langsung diberikan kepada output.

2. Kompresi dimulai dengan metode LZ77 dan diteruskan dengan pengkodean pohon Huffman. Pohon Huffman dalam mode ini merupakan pohon Static Huffman, jadi tidak memerlukan ruang ekstra untuk menyimpan pohon tersebut.

3. Kompresi dimulai dengan metode LZ77 dan diteruskan dengan pengkodean pohon Huffman. Pada mode ini terdapat perbedaan karena dirancang oleh kompresor dan disimpan bersama data-data yang dikompresi. Pohon Huffman ini disebut juga sebagai pohon Huffman dinamik.

\section{Reserved}

Adapun tahap kompresi Deflate dimulai dengan melakukan eliminasi karakter string kembar (implementasi algoritma kompresi LZ77) yang dilakukan dari hasil pembacaan tiap block yang diproses. Apabila pada awal block tidak ditemukan pola maka akan mengaktifkan mode 1 pada block tersebut, yakni mode tidak dikompresi. Ketika ditemukan pola karakter kembar maka dituliskan sebuah referensi berisi panjang sekuen dan jaraknya dari awal block. Kemungkinan panjang block adalah 2-258 Bytes dan kemungkinan jarak sliding windownya adalah 1-32.768 Bytes. Tahap berikutnya adalah penggunaan pohon Huffman, yaitu mengganti setiap data yang sering muncul dengan simbol tertentu yang memiliki bit yang lebih pendek. Mode kedua menggunakan pohon Static Huffman yang artinya karakter yang dibutuhkan untuk melakukan dekompresi file tidak disertakan dalam file terkompresi. Mode ketiga adalah menggunakan Dynamic Huffman Compression, yang artinya harus mendapatkan seluruh karakter yang akan dilakukan untuk melakukan kompresi terhadap block. Karakter tersebut disimpan setelah data, dan sifat karakter encode ini adalah fixed. Penggolongan karakter encode Dynamic Huffman Compression dapat dilihat pada RFC 1951 Nantinya akan didapatkan hasil tiap block kompresi yang merupakan hasil teks terkompresi[3]. Penyimpanan arsip juga dapat dilakukan dengan menggunakan owncloud sebagai penyimpanan berbasis web yang mudah untuk dikembangkan [4].

\section{Tahapan Penelitian}

Metode penelitian merupakan tata cara dalam tahapan penelitian pada dasarnya adalah tahapan-tahapan antara konsep-konsep yang ingin diamati atau diukur melalui penelitian yang akan dilakukan. Tahap Penelitian dapat dilihat pada Gambar 3.1. Model penyimpanan berbasis cloud juga dapat digunakan menggunakan API programming [5].

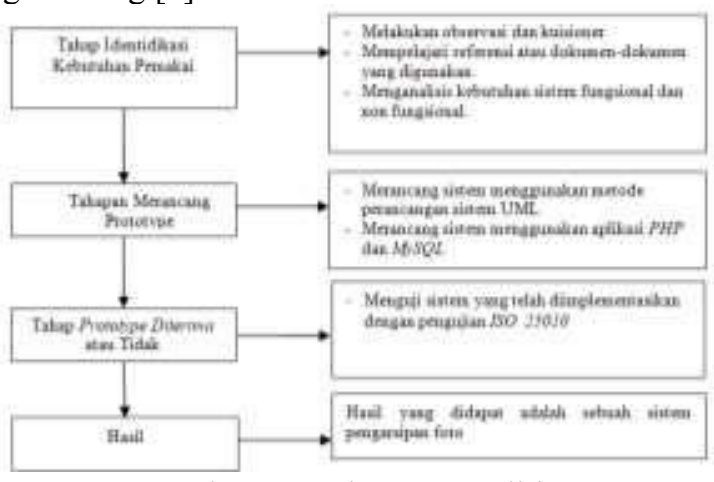

Gambar 3.1 Tahapan Penelitian 
Rancangan sistem dalam tahap ini digunakan untuk menggambarkan desain sistem yang diusulkan dengan menggunakan permodelan UML (Unifield Modeling Language) yang berorientasi objek yaitu use case dan activity diagram yang dapat mempermudah pembuatan sistem.

Berikut adalah deskripsi pendefinisian aktor pada sistem yang dikembangkan.

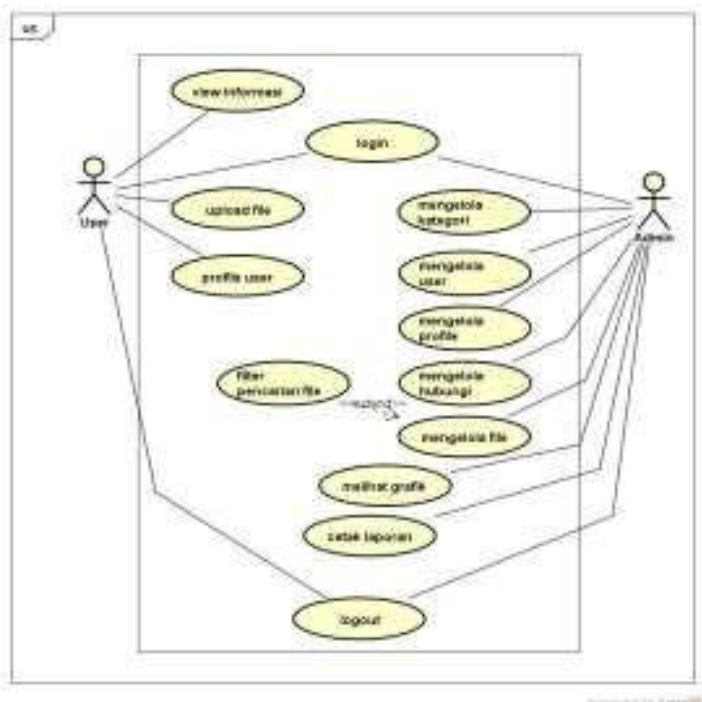

Gambar 3.2 Use diagram sistem

Activity diagram menggambarkan struktur sistem dari segi pendefinisian yang akan dibuat untuk membangun sistem. Dapat dilihat pada gambar 3.3 :

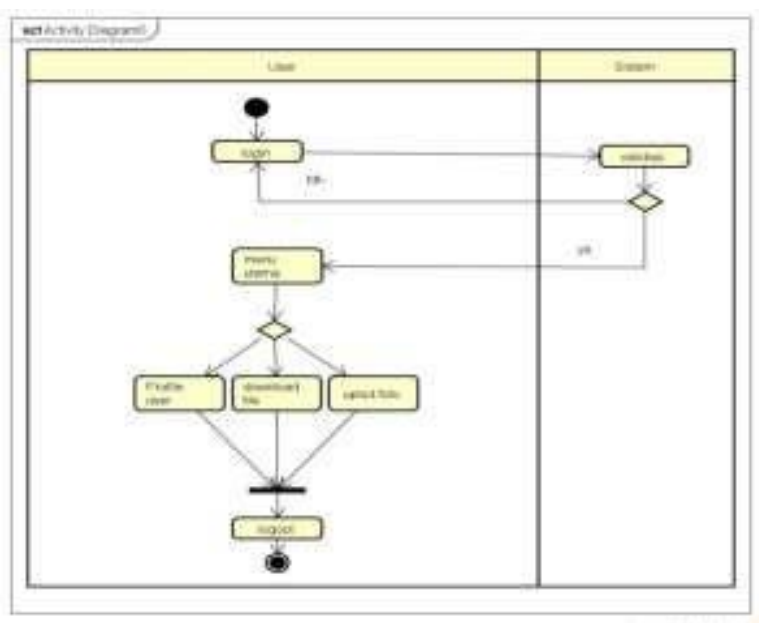

Gambar 3.3 Activity Diagram uer

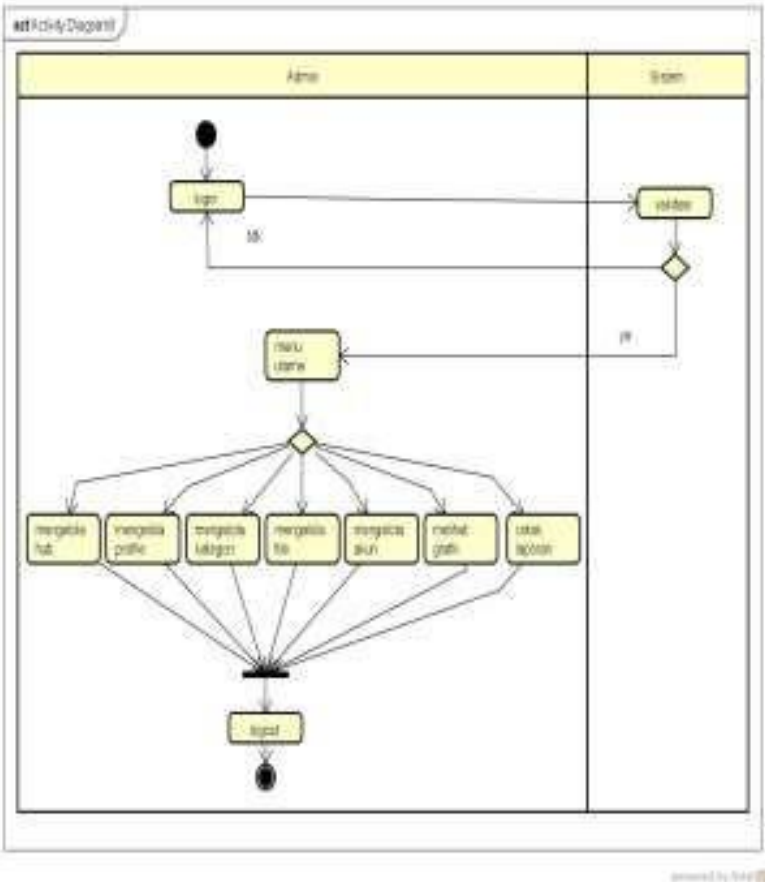

Gambar 3.4 Activity Diagram Admin

\section{Hasil dan Pembahasan}

\subsection{Implementasi Program}

Bab ini akan menjelaskan tentang pembuatan program pendaftaran santri baru, dengan memberikan contoh tampilan form, Implementasi merupakan tahap dimana sistem siap dioperasikan pada tahap sebenarnya, sehingga akan diketahui apakah sistem yang akan dibuat benar-benar dapat menghasilakan tujuan yang diinginkan.

\section{Menu Login}

Menu Login adalah menu sigin dan registrasi untuk masuk kedalam sistem bagi pelanggan, admin dan juga pimpinan. Pelanggan yang sudah memiliki akun dapat langsung memasukan username/email dan password. Dapat dilihat pada gambar dibawah ini :

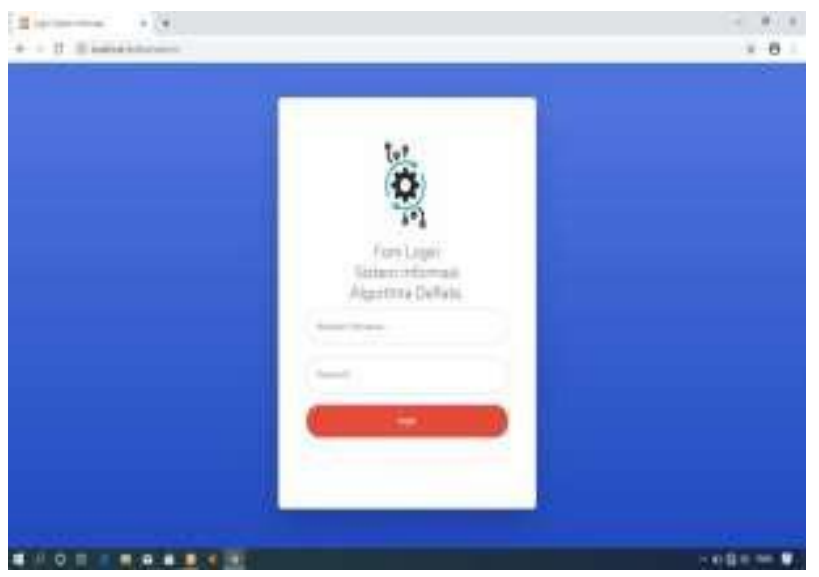

Gambar 4.1 Halaman Login 


\section{Halaman Utama}

Menu utama adalah menu yang menampilkan halaman utama pelanggan yang telah melakukan login. Dapat dilihat pada gambar dibawah ini :

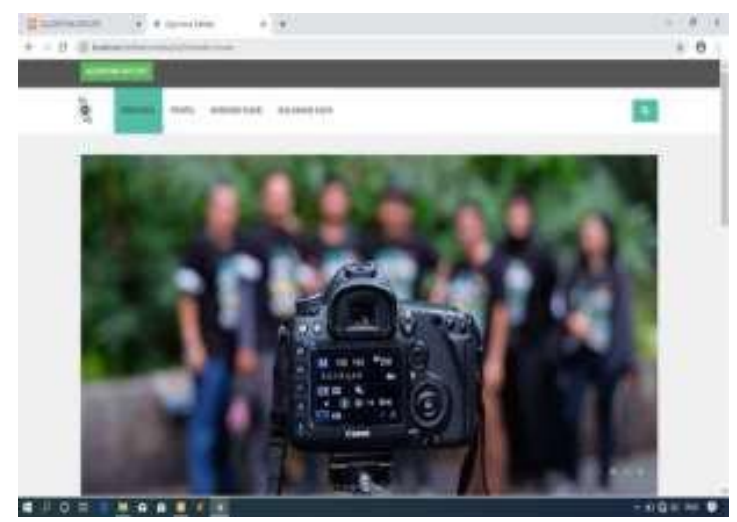

Gambar 4.2 Halaman user

\section{Halaman Upload File}

Menu upload file adalah menu untuk melakukan penyimpanan foto. Dapat dilihat pada gambar dibawah ini :

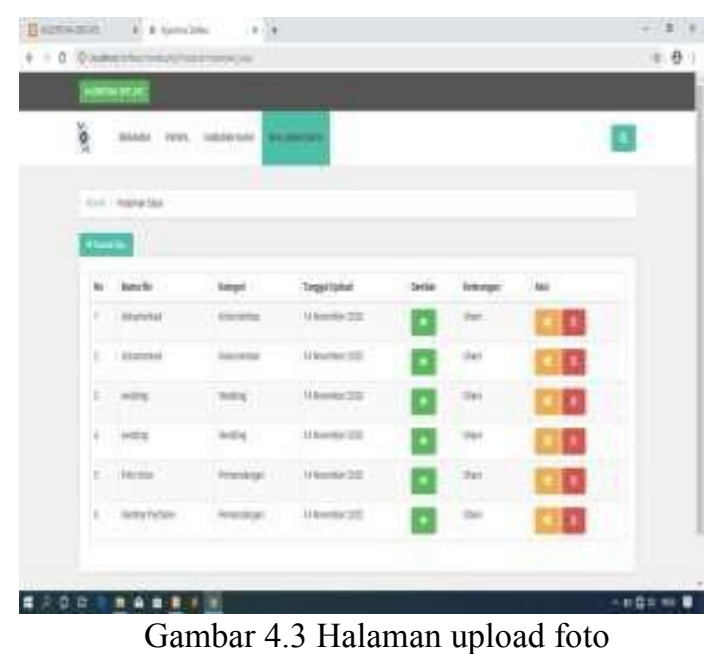

Selanjutnya jika telah mengklik tombol tambah maka akan muncul form untuk melakukan penyimpanan foto. Dapat dilihat pada gambar dibawah ini :

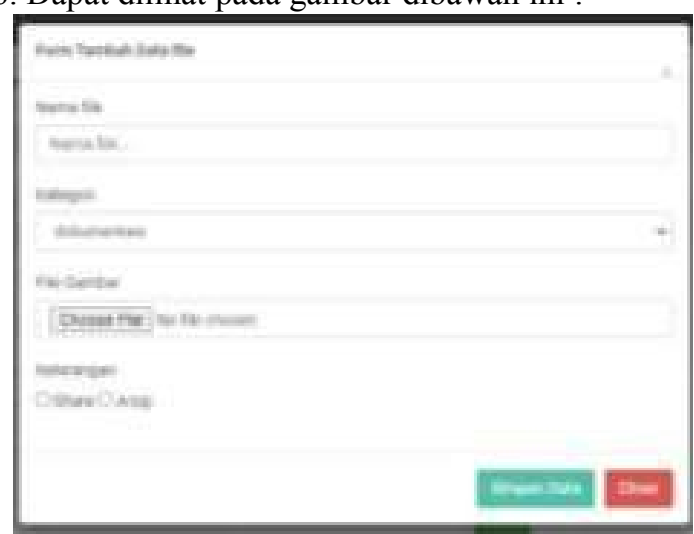

Gambar 4.4 Upload file foto

\section{Menu Profile}

Menu profile adalah menu untuk melakukan edit data user. Dapat dilihat pada gambar dibawah ini :

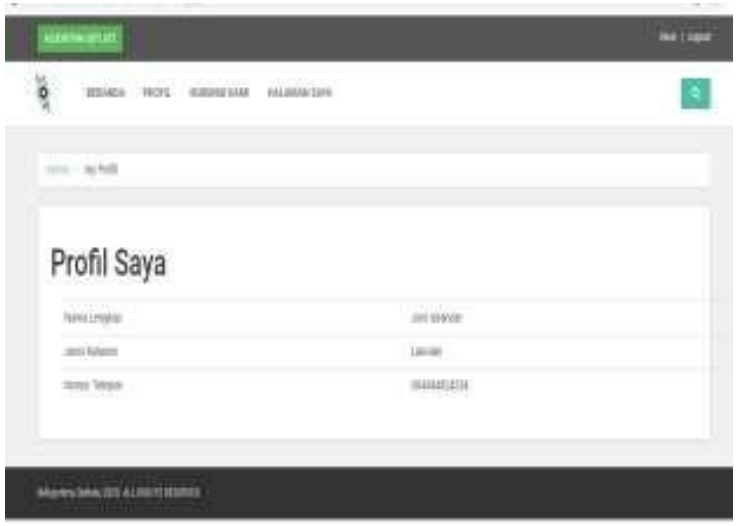

Gambar 4.5 Halaman profile

\section{Menu Download File}

Menu download adalah menu untuk pengunduhan foto yang diarsip. Dapat dilihat pada gambar dibawah ini :

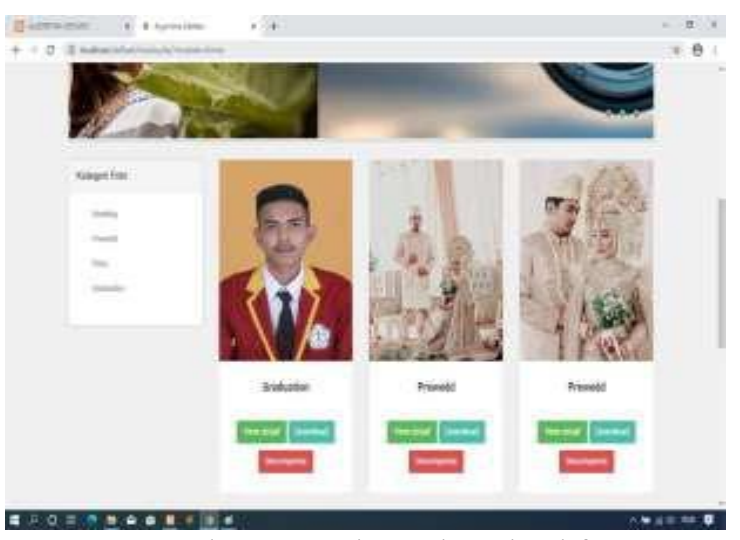

Gambar 4.6 Halama download foto

\section{Hasil Pengujian}

\subsection{Hasil Penilaian Keseluruhan}

Berikut hasil pengujian secara keseluruhan pada aplikasi dapat dilihat pada tabel 5.1.

Tabel 5.1 Hasil Keseluruhan Pengujian

\begin{tabular}{ccccc}
\hline Aspek & \multicolumn{2}{c}{ Skor Aktual Skor Ideal } & $\begin{array}{c}\text { \% Skor } \\
\text { Aktual }\end{array}$ & Kriteria \\
\hline Fuctinonality & 233 & 280 & 83,21 & Baik \\
Usability & 265 & 280 & 94,64 & Sangat Baik \\
Total & 498 & 560 & 88,93 & Baik \\
\hline
\end{tabular}




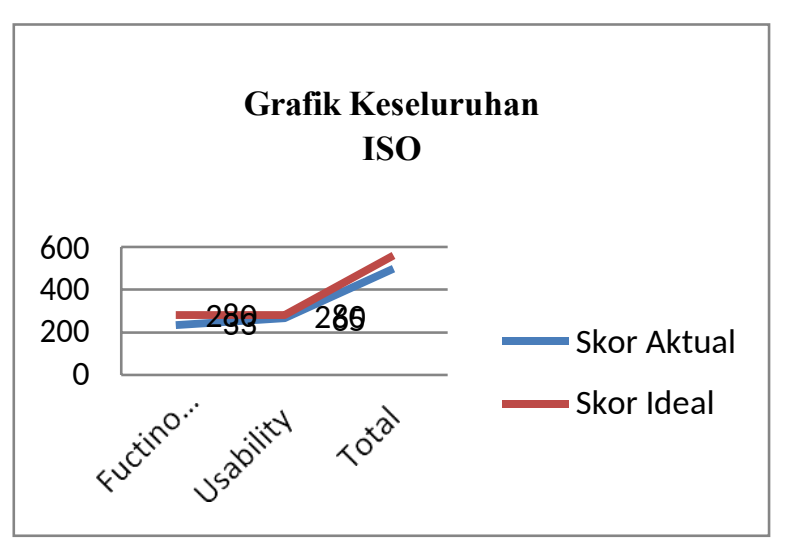

Gambar 5.1 Grafik Keseluruhan Pengujian ISO

Berdasarkan hasil pengujian yang telah dilakukan dengan melibatkan 4 Responden bahwa kesimpulan kualitas kelayakan perangkat lunak yang dihasilkan memiliki persentase keberhasilan dengan total rata-rata $\mathbf{8 8 . 9 3 \%}$. Sehingga dapat disimpulkan bahwa nilai persentase yang diperoleh menunjukkan kualitas perangkat lunak secara keseluruhan mempunyai skala "Sangat Baik"

\section{Kesimpulan}

Berdasarkan pembahasan dari penulisan laporan skripsi dapat diambil kesimpulan yaitu Pembangunan sistem penyimpanan foto berbasis web pada Studio Muezzart dan MySQL sebagai database. Sistem yang dibangun menggunakan algoritma deflate untuk mengkompres ukuran foto menjadi kecil. Dalam pembangunan sistem ini akan menggunakan metode pengembangan prototype dan rancangan sistem menggunakan $U M L$. Implementasi sistem ini menggunakan PHP dan MySQL. Hasil pengujian yang telah dilakukan dengan melibatkan 4 Responden bahwa kesimpulan kualitas kelayakan perangkat lunak yang dihasilkan memiliki persentase keberhasilan dengan total rata-rata $88.93 \%$.

\section{Daftar Pustaka}

[1] A. Fitriansah, "Dan Deflate Pada Berbagai Jenis File Performance Comparison Analysis Of Lzw , Huffman And Deflate Compression Algorithms On Various Files 1 . 1 Latar Belakang Seiring Dengan Perkembangan Waktu Dan Teknologi , Maka Teknologi Informasi Juga Mengalami Perkem," Telkom, Pp. 1-9, 2016.

[2] D. Salomon, Data Compression, 44th Ed. London: Springer-Verlag, 2007.

[3] Deutsch, Peter, Gailly, Jean-Loup, And Zlib, "Compressed Data Format Group Specification Version 3.3 Network Working," 1996.

[4] Jupriyadi, J. and Prabowo, R., 2017. Implementasi Owncloud Sebagai Private Storage Berbasis Web Pada Perguruan Tinggi Xyz. Prosiding Semnastek.

[5] Sontana, I., Rahmatulloh, A. and Rachman, A.N., 2019. Application Programming Interface Google Picker Sebagai Penyimpanan Data Sistem Informasi Arsip Berbasis Cloud. Jurnal Nasional Teknologi dan Sistem Informasi, 5(1), pp.25-32. 